\title{
Data report: stratigraphic correlation of Site U1396 and creation of a composite depth scale and splice $^{1}$
}

\section{Chapter contents}

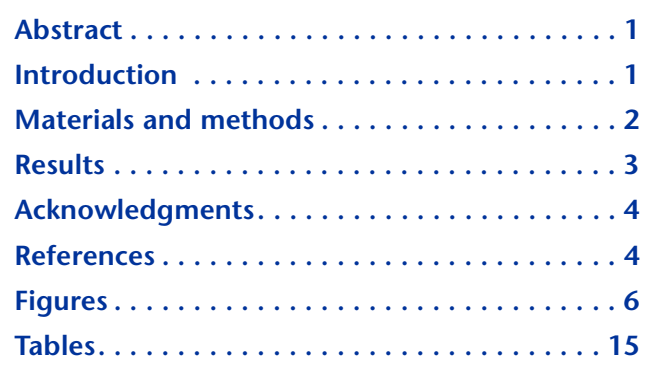

${ }^{1}$ Hatfield, R.G., 2015. Data report: stratigraphic correlation of Site U1396 and creation of a composite depth scale and splice. In Le Friant, A., Ishizuka, O., Stroncik, N.A., and the Expedition 340 Scientists, Proceedings of the Integrated Ocean Drilling Program, 340: Tokyo (Integrated Ocean Drilling Program Management International, Inc.). doi:10.2204/iodp.proc.340.202.2015

2104 CEOAS Administration Building, Oregon State University, Corvallis Oregon 97331, USA. rhatfiel@coas.oregonstate.edu
Robert G. Hatfield ${ }^{2}$

\begin{abstract}
Composite depth scales and spliced records are routinely generated stratigraphic data sets on paleoceanographic Integrated Ocean Drilling Program (IODP) expeditions. They are constructed to generate a complete stratigraphic section that is more representative of a site than records from individual holes. Although sediments recovered from the three holes cored at Site U1396 during IODP Expedition 340 were correlated on board the JOIDES Resolution, a composite depth scale and complete stratigraphic section were not generated. After correction of the shipboard data for small positional errors, I used the shipboard acquired physical property data sets to recorrelate the stratigraphy and generate both a composite depth scale and a spliced record for Site U1396. Using the shipboard-generated paleomagnetic reversal record, I then estimated sedimentation rate at Site U1396 since 4.5 Ma.
\end{abstract}

\section{Introduction}

A major objective of Integrated Ocean drilling Program (IODP) Expedition 340 Site U1396 was to utilize the marine record to characterize the eruptive history of Montserrat. Three holes were cored at the site with the advanced piston corer (APC) system; two of them were quasicontinuous $140.5 \mathrm{~m}$ (Hole U1396A) and 145.9 m (Hole U1396C) records, whereas Hole U1396B was a single $10 \mathrm{~m}$ core $(340-\mathrm{U} 1396 \mathrm{~B}-2 \mathrm{H})$ taken to replicate a disturbed interval (Core 340-U1396A-2H) in Hole U1396A. Shipboard-derived biostratigraphic and paleomagnetic data sets revealed that the sediment and intercalated tephra record at Site U1396 date back 4.5 My to the early Pliocene (see the "Site U1396" chapter [Expedition 340 Scientists, 2013]). As subaerial radiometric ages place the origin of Montserrat around 2.5 Ma (Harford et al., 2002) Site U1396 is an important sedimentary sequence potentially capable of addressing fundamental questions about the evolution of the Lesser Antilles volcanic arc.

Many of the scientific objectives for Site U1396 required recovery of a continuous and complete stratigraphic section. Continuous sedimentary sections cannot be recovered from a single borehole because gaps in recovery occur between successive cores. Furthermore, Core 340-U1396A-2H suffered a shattered liner, and two 10 $\mathrm{cm}$ whole-round (WR) samples were taken from every core in Hole U1396C, resulting in irregular gaps in records from individ- 
ual holes. A continuous complete section can be constructed by combining intervals from all three holes to bridge gaps and replace disturbed intervals. This can be achieved by (1) correlating physical property data to identify coeval horizons between cores, which may be substantially offset in depth, and (2) mapping individual holes onto a common depth scale that allows the generation of a spliced record and development of a complete stratigraphic section. Shipboard correlation of the three holes from Site U1396 was accomplished using Analyseries (Paillard et al., 1996) (see the "Site U1396" chapter [Expedition 340 Scientists, 2013]). However, this methodology linearly interpolated data between assigned tie points, artificially "stretching" and "squeezing" the sequence, which may not reflect sediment deposition processes. This methodology also retained the core depth below seafloor (CSF-A) depth scale (e.g., Manga et al., 2012; Jutzeler et al., 2014; Wall-Palmer et al., 2014), which is subject to numerous errors and inaccuracies. Here, I outline the methodology used for correlating Holes U1396AU1396C and develop a composite depth scale and splice for Site U1396.

\section{Materials and methods}

The method used to generate a composite depth scale and splice is adopted from and largely follows the strategy developed for paleoceanographic IODP expeditions (e.g., Expedition 303 Scientists, 2006; Expedition 323 Scientists, 2011; Expedition 339 Scientists, 2013; Jaeger et al., 2014).

\section{A note on depth scales}

In its simplest terms, the CSF-A depth scale is based on the length of the drill string plus the length of the material recovered during the process of coring. The zero depth point in the CSF-A scale is defined by the uppermost sediment in the first core (commonly referred to as the "mudline" core); the depth to any point along that core is then determined by adding the distance that point occurs from the mudline. The length of each recovered core is then used to advance the drill string, setting a new datum for subsequent cores from the same hole. The CSF-A scale is inaccurate because of ship heave (which is not corrected for in APC coring), tidal and nontidal variations in sea level, and other sources of measurement error.

The goal of constructing a composite depth scale is to place coeval, laterally continuous stratigraphic features into a common frame of reference by manipulating the CSF-A depth of individual cores to maximize physical property correlation between holes. This is a rather more elegant method of depth scale construction because instead of relying on the drill string measurement, the composite core depth below seafloor (CCSF-A) is built by continuously correlating physical features downhole from the mudline. The core with the most representative mudline defines the top of the stratigraphic section and becomes the anchor in the CCSF-A depth scale. It is typically the only core in which the depths are the same for both the CSF-A and CCSF-A scales. Each core downhole is tied to the composite section by adding or subtracting a depth offset (a constant) that best aligns the observed lithologic variations for cores from adjacent holes. Using this method, no cores are stretched or squeezed to facilitate correlation but are instead "hung" next to each other to build the composite section. It is therefore not usually possible to align all features perfectly between holes; in such cases, offsets are chosen to maximize correlations over the whole core.

In the process of constructing the composite section, the CCSF-A scale is always almost expanded relative to the CSF-A scale. This expansion is typically reported as 5\%-20\% (e.g., Expedition 303 Scientists, 2006; Expedition 323 Scientists, 2011; Expedition 339 Scientists, 2013; Jaeger et al., 2014). Although it is often difficult to identify the specific cause for the growth factor, it is widely thought to result from the coring process and includes (but is not limited to) stretching and squeezing, decompression and degassing, and curation. In response to this growth, the CCSF-B (composite core depth below seafloor, method B) depth scale is intended to correct the CCSF-A scale for any empirically observed expansion (Jaeger et al., 2014). CCSF-B depths are produced by correcting for the average growth of the CCSF-A scale relative to the CSF-A scale over a sufficiently long interval that random variations in drill pipe advance due to ship heave, tides, and other factors are averaged to be negligible (Jaeger et al., 2014). This scaling produces a complete composite section sequence that is the same length as the total cored interval. As the CCSF-B scale is a closer representation of the actual drilling depths than the CCSF-A scale, it should be the scale used for estimation of sediment accumulation rate. However, because the CCSF-B scale provides an estimate of sediment thickness, intervals that are targeted for sampling within each core section are better represented by the uncompressed CCSF-A scale (Jaeger et al., 2014).

\section{Correlation}

Given the diverse lithology of the sediments recovered at Site U1396, Holes U1396A-U1396C were primarily correlated using shipboard magnetic suscepti- 
bility (MS), which was acquired at $2.5 \mathrm{~cm}$ intervals prior to the core being split on the Whole-Round Multisensor Logger (WRMSL). To independently corroborate MS correlations and assist decisions if MS correlation became ambiguous, density data measured through gamma ray attenuation (GRA) on the WRMSL at $2.5 \mathrm{~cm}$ intervals and natural gamma radiation (NGR) radiation measured at $10 \mathrm{~cm}$ intervals on the NGR system were also used for correlation. The first and last data points from each measurement were masked in the data set because they contain volumetric edge effects in MS, GRA, and NGR that did not result from lithologic variances. Physical property data were imported into the Corewall Correlator software (version 2.0; http://www.corewall.org), which provides depth shifting capabilities and associated correlation values that were used to maximize the correlation between cores from different holes.

During correlation, it was noted that the MS data reported for Sections 340-U1396C-9H-6 and 9H-7 suffered positioning errors during measurement on the WRMSL. The WRMSL-assigned length of Section 9H7 in the LIMS database is $143 \mathrm{~cm}$, but the section is only $70 \mathrm{~cm}$ in length. This is manifested in the WRMSL-derived MS data as a $72.5 \mathrm{~cm}$ interval of repeated measurements between 83.35 and $84.05 \mathrm{~m}$ CSF-A (Fig. F1A). Comparison of the WRMSL MS data (Fig. F1A) to the MS point source data collected on the Section Half Multisensor Logger (SHMSL) confirms this discrepancy (Fig. F1B). Removal of $72.5 \mathrm{~cm}$ of repeated MS data in the WRMSL record produces new WRMSL CSF-A depths for Sections 9H6 and 9H-7 (Fig. F1C; Table T1) and a data set that now reflects the true core length and better replicates the SHMSL data. The amended CSF-A data for Core $9 \mathrm{H}$ is used for correlation and in construction of the CCSF-A depth scale.

\section{Splice development}

Once both holes are mapped onto the common CCSF-A depth, the most representative continuous section can be chosen to reflect the complete record of the site. The spliced record is sampled to avoid missing and disturbed intervals by using sections from more complete holes. At Site U1396, Core 340U1396B-2H was used to replace disturbed Core $\mathrm{U} 1396 \mathrm{~A}-2 \mathrm{H}$ and the remainder of the record switches between Hole U1396A and Hole U1396C to bridge WR and core gaps. The choice of splice tie points is somewhat subjective, but attempts were made to avoid the uppermost and lowermost parts of core, which may be more susceptible to disturbance, and to utilize, where possible, the longest possible sections within individual cores to reduce the num- ber of necessary tie points. Data within the splice are assigned an additional CCSF-D depth. These depths are exactly the same as the CCSF-A depths; assignment of a CCSF-D scale to an interval simply implies it is incorporated within this spliced record. Because $10 \mathrm{~cm}$ WR samples were taken at 3-6 m intervals in Hole U1396C, the resulting splice will likely lean more heavily on cores from Hole U1396A.

\section{Results}

The composite depth scale for Site U1396 was constructed from 0.0 to $153.13 \mathrm{~m}$ CCSF-A. Section 340U1396C-1H-1 was selected as the mudline core and serves as the anchor for the rest of the composite depth scale. All other cores are offset relative to Section $1 \mathrm{H}-1$ by correlating variations in core logging data between holes on a core-by-core basis using Correlator. Because of the highly disturbed nature of Core 340-U1396A-2H, it was not possible to correlate this core to the other holes. Core lengths, offsets, and the CSF-A and CCSF-A depth scales are listed in Table T1. Core 340-U1396C-13H was a partial stroke and experienced basal flow-in of $\sim 4 \mathrm{~m}$ of pumiceous sand (Jutzeler et al., 2014). Oversampling of this unit and its incorporation in calculating the target top depth of Core 340-U1396C-14H in the CSF-A depth scale meant that the interval in Hole U1396C that could potentially be used to bridge Cores 340U1396A-13H and $14 \mathrm{H}$ was not recovered. Therefore, deeper Cores $14 \mathrm{H}$ and $15 \mathrm{H}$ and Cores 340-U1396C$14 \mathrm{H}$ and $15 \mathrm{H}$ can be correlated to each other, but they cannot be directly tied into the overlying continuous CCSF-A scale, resulting in a floating CCSF-A scale below Core 340-U1396A-14H. Linear regression of the CSF-A and CCSF-A scales for all holes up to and including Core 340-U1396C-13H $(N=25, r=$ $>0.99$ ) allows estimation of the depth offset required to integrate Core 340-U1396A-14H (which serves as the anchor for the floating CCSF-A scale) into the overlying CCSF-A scale. Although these cores are assigned a CCSF-A depth, they must be treated with caution because these depths are predicted using the offset behavior of the overlying sections and not directly assigned. Linear regression of the CSF-A and CCSF-A scales for each hole reveal growth factors of 1.1096 and 1.0992 for Hole U1396A and Hole U1396C, respectively (Fig. F2). This calculation results in an $\sim 11 \%$ increase in the CCSF-A scale relative to CSF-A depths for Hole U1396A and $10 \%$ for Hole U1396C.

Without nonlinear manipulation of individual cores, it is not possible to align all features between holes. However, significant improvement is observed in the correlation of MS between holes using the CCSF-A 
scale $\left(R^{2}=0.52\right)$ over the CSF-A scale $\left(R^{2}=0.14\right)$ (Fig. F3). MS for Holes U1396A-U1396C on the newly developed CCSF-A depth scale is shown in the lower panels of Figure F4. The spliced record is shown in the upper panel and is color coded (and labeled) by the hole that the data in the splice is from; splice tie points are listed in Table T2. The goal of creating this splice was to ensure the most complete and representative intervals were identified and integrated into one continuous record. Although in-splice data correlate well at the tie points, off-splice data should not be expected to directly correlate between holes. Physical property data should be consulted to assess where off-splice data fits into the spliced CCSF-D depth scale.

Using the shipboard paleomagnetic reversal record (see the "Site U1396" chapter [Expedition 340 Scientists, 2013]), mass accumulation rates for the site can now be calculated. First, however, the CCSF-A scale must be corrected for the growth factor. Linear regression through the core tops of all three holes at Site U1396 indicates that a scaling factor of 0.9057 $(90.57 \%)$ is required to compress the CCSF-A depths into a scale that has the same total depth as the interval drilled (Fig. F5). The compressed CCSF-B depth scale is listed in Table T1 alongside the CSF-A and CCSF-A scales. The declination of the shipboard paleomagnetic record was azimuthally orientated with the FlexIt tool (see the "Site U1396" chapter [Expedition 340 Scientists, 2013]), and polarity reversal horizons were identified by the $180^{\circ}$ change in declination that accompanies a magnetic polarity reversal. These horizons were recorded at Site U1396 as the maximum depth (the last point at which stable polarity was recorded), the minimum depth (the first point at which stable antipodal polarity was established), and the midpoint (average) of the two. These three depths are reported on the CCSF-A depth scale in Table T3. The Cobb Mountain Subchron (C1r.2r1n) between 1.173 and $1.185 \mathrm{Ma}(\mathrm{Ogg}, 2012)$ was difficult to identify in this relatively low resolution record, so the record remains untied between 1.072 and $1.778 \mathrm{Ma}$. It is also important to note that no eventdepth correction was made for the assumed instantaneous deposition of tephra whose eruption frequency may have been greater between 3.5 and 4.5 Ma than after 3.5 Ma (Stinton et al., 2014) relative to the slower accumulation of carbonate-dominated autochthonous background sediment. Using the geomagnetic polarity timescale of Ogg (2012) and the CCSF-B depth scale and linearly interpolating between tie points, the resulting age model is shown in Figure F5; sedimentation rates (with low and high estimates de- rived from the minimum and maximum depths) are shown in Figure F5 alongside the LR04 benthic oxygen isotope stack (Lisiecki and Raymo, 2005) for reference. The average sedimentation rate over the whole record is $30.7 \mathrm{~m} / \mathrm{My}$, however mid-late Pliocene and early Pleistocene sedimentation rates (4.493-2.128 My; $41.6 \mathrm{~m} / \mathrm{My})$ are higher than rates since the early Pleistocene (<2.128 My; $18.7 \mathrm{~m} / \mathrm{My})$.

\section{Acknowledgments}

This research was supported by an Expedition 340 Post-expedition Activity Award by the United States Science Support Program (USSSP) and a National Science Foundation Ocean Drilling Program Grant (OCE-1260671) to R.G. Hatfield and Dr. Joseph S. Stoner. This research used shipboard data acquired during Integrated Ocean Drilling Program Expedition 340, and I would like to thank both the shipboard science party and the captain and crew of the $\mathrm{R} / \mathrm{V}$ JOIDES Resolution during the expedition. I would also like to thank the USSSP for travel funding while participating in Expedition 340 activities during the seaward leg and during sampling and postcruise meetings and Toshi Yamazaki for review comments that improved this data report.

\section{References}

Expedition 303 Scientists, 2006. Site U1302-U1308 methods. In Channell, J.E.T., Kanamatsu, T., Sato, T., Stein, R., Alvarez Zarikian, C.A., Malone, M.J., and the Expedition 303/306 Scientists, Proceedings of the Integrated Ocean Drilling Program, 303/306: College Station, TX (Integrated Ocean Drilling Program Management International, Inc.). http://dx.doi.org/10.2204/ iodp.proc.303306.102.2006

Expedition 323 Scientists, 2011. Methods. In Takahashi, K., Ravelo, A.C., Alvarez Zarikian, C.A., and the Expedition 323 Scientists, Proceedings of the Integrated Ocean Drilling Program, 323: Tokyo (Integrated Ocean Drilling Program Management International, Inc.). http://dx.doi.org/ 10.2204/iodp.proc.323.102.2011

Expedition 339 Scientists, 2013. Methods. In Stow, D.A.V., Hernández-Molina, F.J., Alvarez Zarikian, C.A., and the Expedition 339 Scientists, Proceedings of the Integrated Ocean Drilling Program, 339: Tokyo (Integrated Ocean Drilling Program Management International, Inc.). http://dx.doi.org/10.2204/iodp.proc.339.102.2013

Expedition 340 Scientists, 2013. Site U1396. In Le Friant, A., Ishizuka, O., Stroncik, N.A., and the Expedition 340 Scientists, Proceedings of the Integrated Ocean Drilling Program, 340: Tokyo (Integrated Ocean Drilling Program Management International, Inc.). http://dx.doi.org/ 10.2204/iodp.proc.340.106.2013 
Harford, C.L., Pringle, M.S., Sparks, R.S.J., and Young, S.R., 2002. The volcanic evolution of Montserrat using ${ }^{40} \mathrm{Ar} /$

${ }^{39} \mathrm{Ar}$ geochronology. Mem.-Geol. Soc. London, 21:93-

113. http://dx.doi.org/10.1144/

GSL.MEM.2002.021.01.05

Jaeger, J.M., Gulick, S.P.S., LeVay, L.J., Asahi, H., Bahlburg, H., Belanger, C.L., Berbel, G.B.B., Childress, L.B., Cowan, E.A., Drab, L., Forwick, M., Fukumura, A., Ge, S., Gupta, S.M., Kioka, A., Konno, S., März, C.E., Matsuzaki, K.M., McClymont, E.L., Mix, A.C., Moy, C.M., Müller, J., Nakamura, A., Ojima, T., Ridgway, K.D., Rodrigues Ribeiro, F., Romero, O.E., Slagle, A.L., Stoner, J.S., St-Onge, G., Suto, I., Walczak, M.H., and Worthington, L.L., 2014. Methods. In Jaeger, J.M., Gulick, S.P.S., LeVay, L.J., and the Expedition 341 Scientists, Proceedings of the Integrated Ocean Drilling Program, 341: College Station, TX (Integrated Ocean Drilling Program). http:/ /dx.doi.org/10.2204/iodp.proc.341.102.2014

Jutzeler, M., White, J.D.L., Talling, P.J., McCanta, M., Morgan, S., Le Friant, A., and Ishizuka, O., 2014. Coring disturbances in IODP piston cores with implications for offshore record of volcanic events and the Missoula megafloods. Geochemistry, Geophysics, Geosystems, 15(9):3572-3590. http://dx.doi.org/10.1002/ 2014GC005447

Lisiecki, L.E., and Raymo, M.E., 2005. A Pliocene-Pleistocene stack of 57 globally distributed benthic $\delta^{18} \mathrm{O}$ records. Paleoceanography, 20(1):PA1003. http:// dx.doi.org/10.1029/2004PA001071

Manga, M., Hornbach, M.J., Le Friant, A., Ishizuka, O., Stroncik, N., Adachi, T., Aljahdali, M., Boudon, G., Breitkreuz, C., Fraass, A., Fujinawa, A., Hatfield, R., Jutzeler, M., Kataoka, K., Lafuerza, S., Maeno, F., Martinez-Colon, M., McCanta, M., Morgan, S., Palmer, M.R., Saito, T., Slagle, A., Stinton, A.J., Subramanyam, K.S.V., Tamura, Y., Talling, P.J., Villemant, B., Wall-Palmer, D., and Wang, F., 2012. Heat flow in the Lesser Antilles island arc and adjacent backarc Grenada Basin. Geochemistry,
Geophysics, Geosystems, 13:Q08007. http://dx.doi.org/ $10.1029 / 2012$ GC004260

Ogg, J.G., 2012. Geomagnetic polarity time scale. In Gradstein, F.M., Ogg, J.G., Schmitz, M.D., and Ogg, G.M. (Eds.), The Geologic Time Scale 2012: Amsterdam (Elsevier), 85-113. http://dx.doi.org/10.1016/B978-0-44459425-9.00005-6

Paillard, D., Labeyrie, L., and Yiou, P., 1996. Macintosh program performs time-series analysis. Eos, Transactions of the American Geophysical Union, 77(39):379. http:// dx.doi.org/10.1029/96EO00259

Stinton, A.J., Hatfield, R.G., and McCanta, M., 2014. Effect of aseismic ridge subduction on volcanism in the NE Lesser Antilles arc [presented at American Geophysical Union 2014 Fall Meeting, San Francisco, California, 1519 December 2014]. (Abstract V32B-07) http:// abstractsearch.agu.org/meetings/2014/FM/V32B07.html

Wall-Palmer, D., Coussens, M., Talling, P.J., Jutzeler, M., Cassidy, M., Marchant, I., Palmer, M.R., Watt, S.F.L., Smart, C.W., Fisher, J.K., Hart, M.B., Fraass, A., Trofimovs, J., Le Friant, A., Ishizuka, O., Adachi, T., Aljahdali, M., Boudon, G., Breitkreuz, C., Endo, D., Fujinawa, A., Hatfield, R., Hornbach, M.J., Kataoka, K., Lafuerza, S., Maeno, F., Manga, M., Martinez-Colon, M., McCanta, M., Morgan, S., Saito, T., Slagle, A.L., Stinton, A.J., Subramanyam, K.S.V., Tamura, Y., Villemant, B., and Wang, F., 2014. Late Pleistocene stratigraphy of IODP Site U1396 and compiled chronology offshore of south and south west Montserrat, Lesser Antilles. Geochemistry, Geophysics, Geosystems, 15(7):3000-3020. http://dx.doi.org/10.1002/2014GC005402

Initial receipt: 26 December 2014

Acceptance: 16 August 2015

Publication: 16 November 2015

MS 340-202 
Figure F1. Comparison of (A) shipboard measured magnetic susceptibility (MS) on the WRMSL versus (B) MS measured on the SHMSL. Note the $72.5 \mathrm{~cm}$ interval in the WRMSL data where repeat measurements are made without the core advancing. These are removed from the WRMSL data to give (C) the WRMSL-corrected data, which agrees more with the SHMSL data.

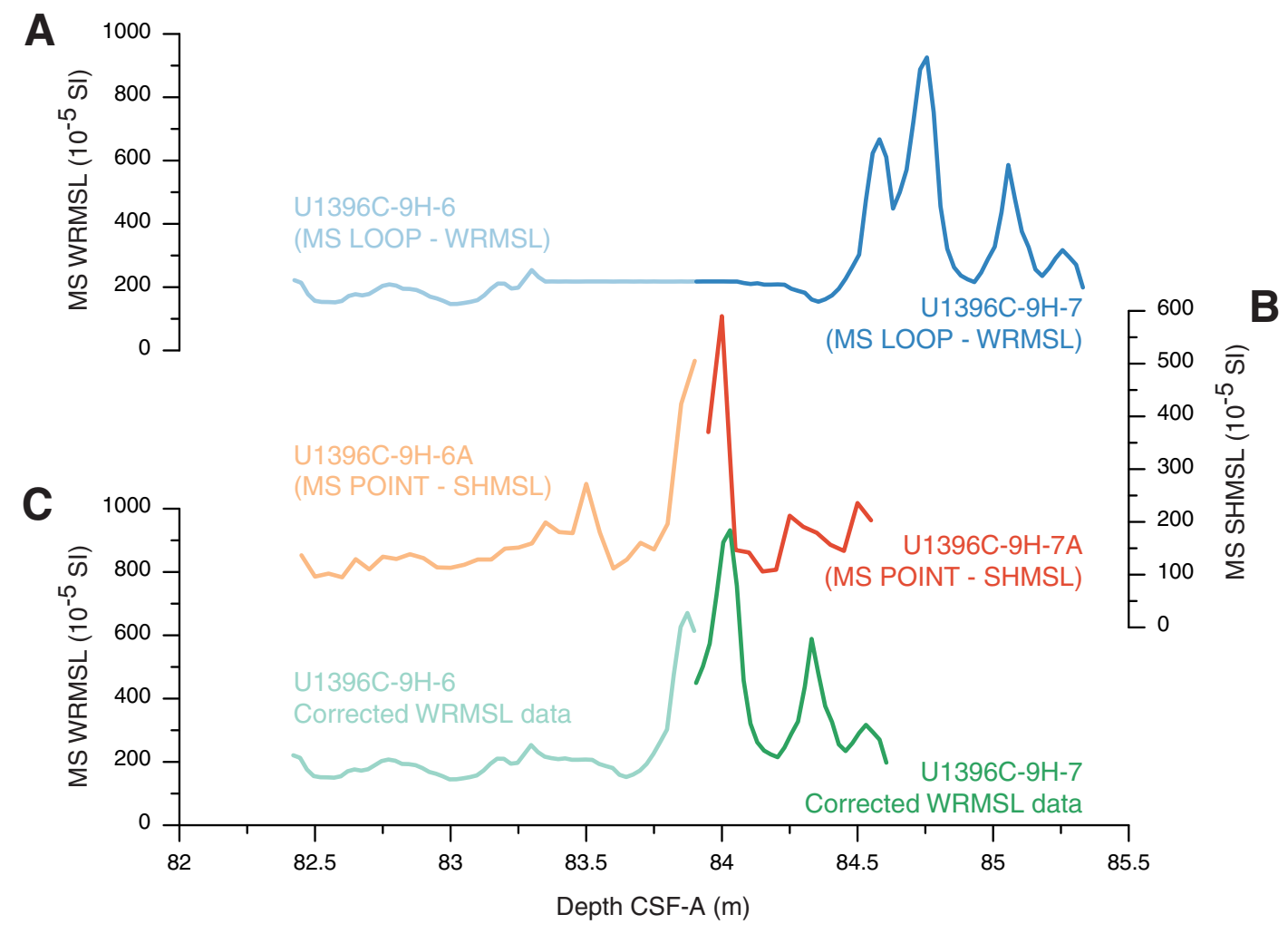


Figure F2. Core top depths for CSF-A vs. CCSF-A, Holes U1396A and U1396C. Lines fit through the core top depths give the relative expansion of the CCSF-A scale relative to the CSF-A scale. Hole U1396A experienced $10.73 \%$ growth and Hole U1396C experienced 9.96\% growth.

Hole U1396A growth factor

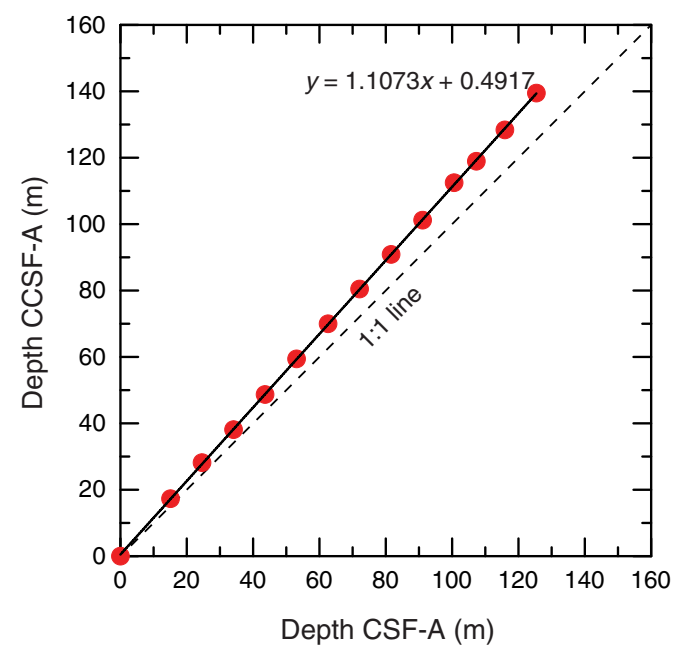

Hole U1396C growth factor

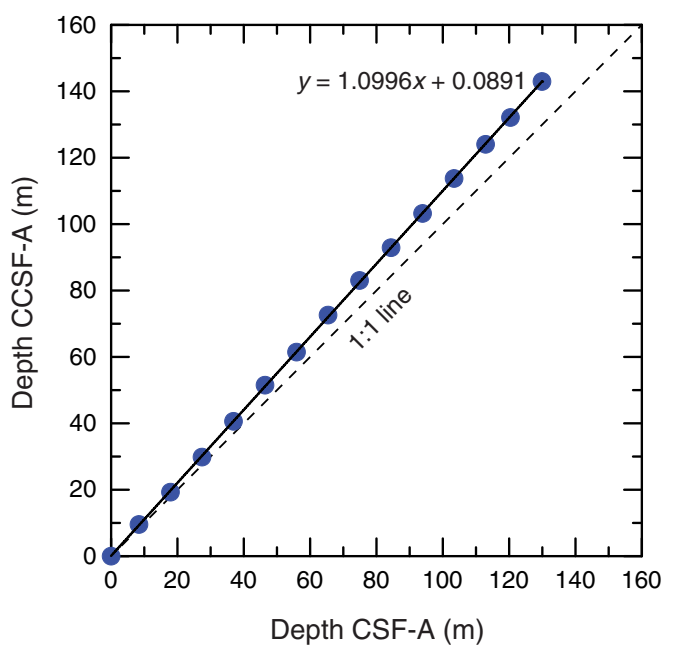


Figure F3. Comparison of magnetic susceptibility (MS) records between Holes U1396A and U1396C using the shipboard-generated CSF-A depth scale and the compiled CCSF-A depth scale. Note the greater agreement between MS records on the CCSF-A depth scale resulting from the data being placed within a common frame of reference.

Depth CSF-A (m)

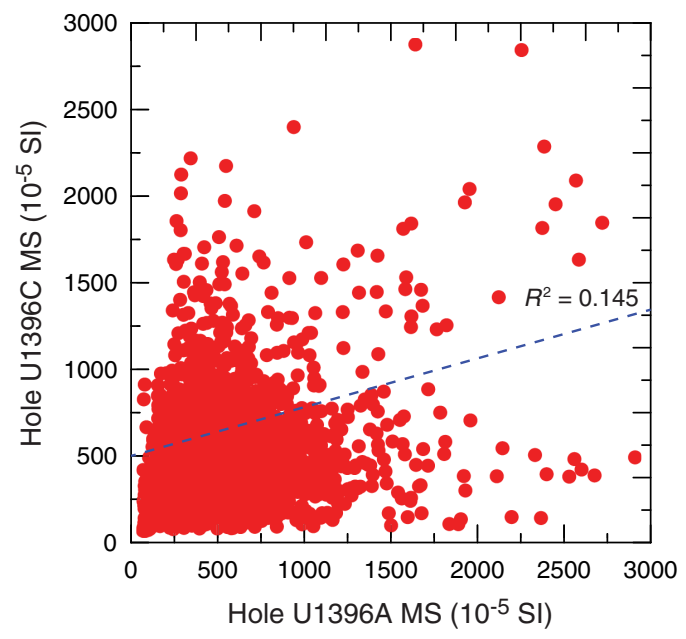

Depth CCSF-A (m)

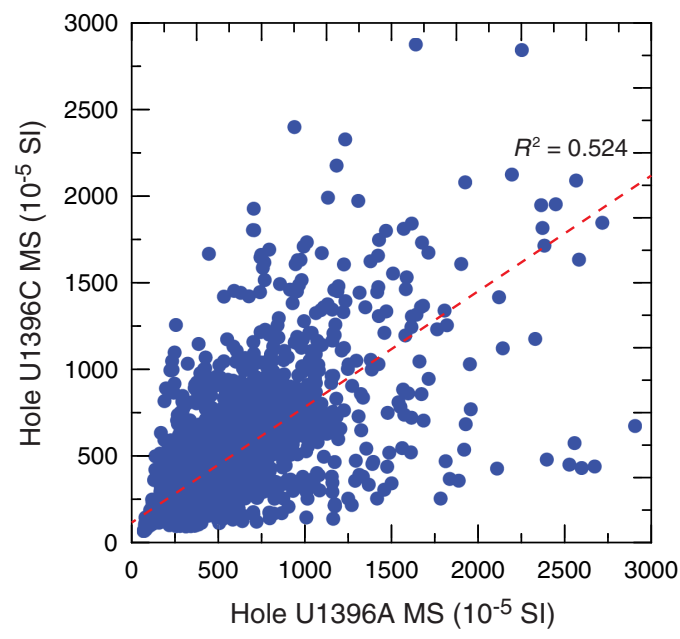


Figure F4. Bottom: magnetic susceptibility (MS) data for Holes U1396A-U1396C. Black numbered arrows = start point and core number. Top: MS data for the interval of the continuous spliced record (CCSF-D). A. 0-40 m CCSF-A. (Continued on next three pages.)

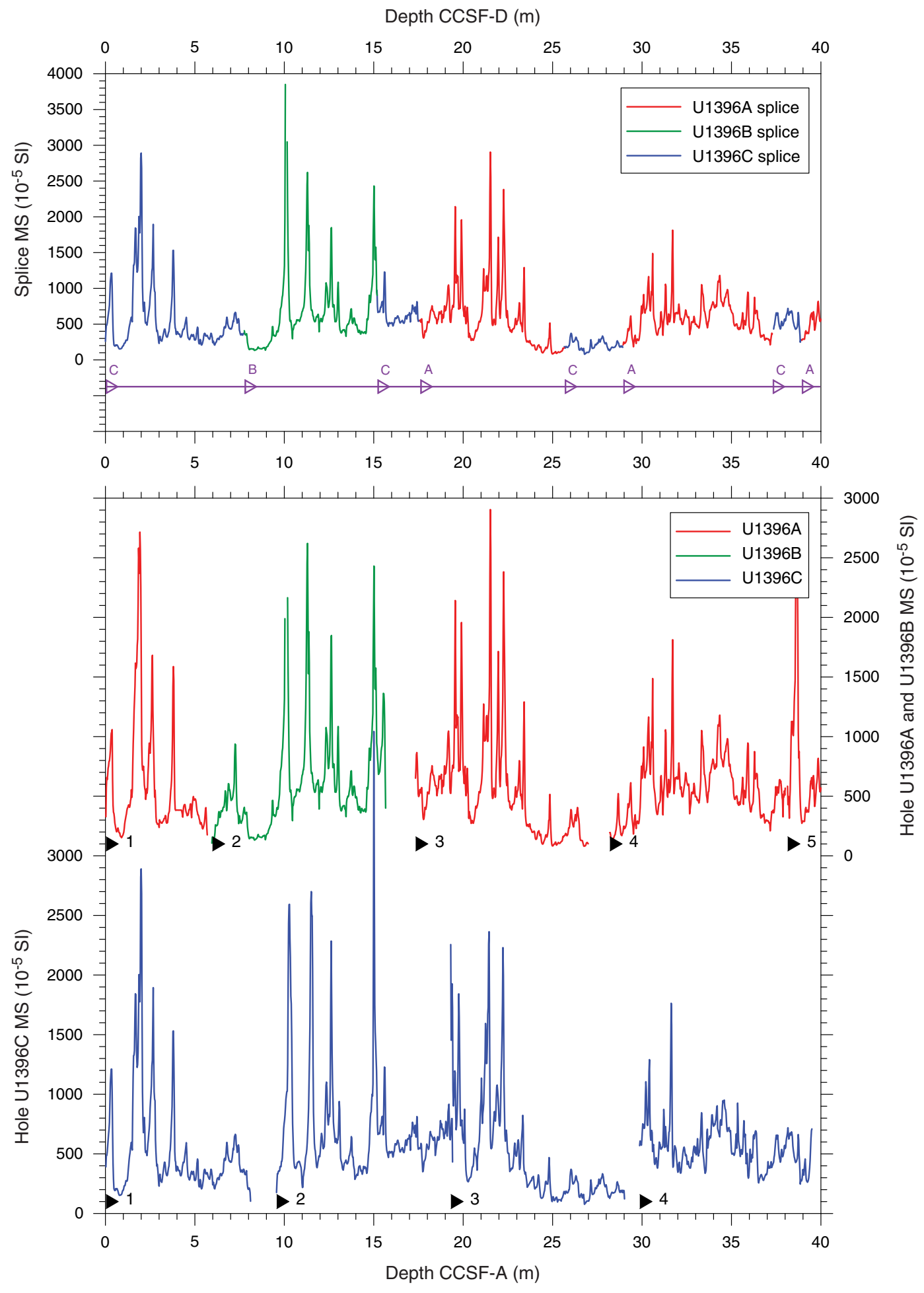


Figure F4 (continued). B. $40-80 \mathrm{~m}$ CCSF-A. (Continued on next page.)
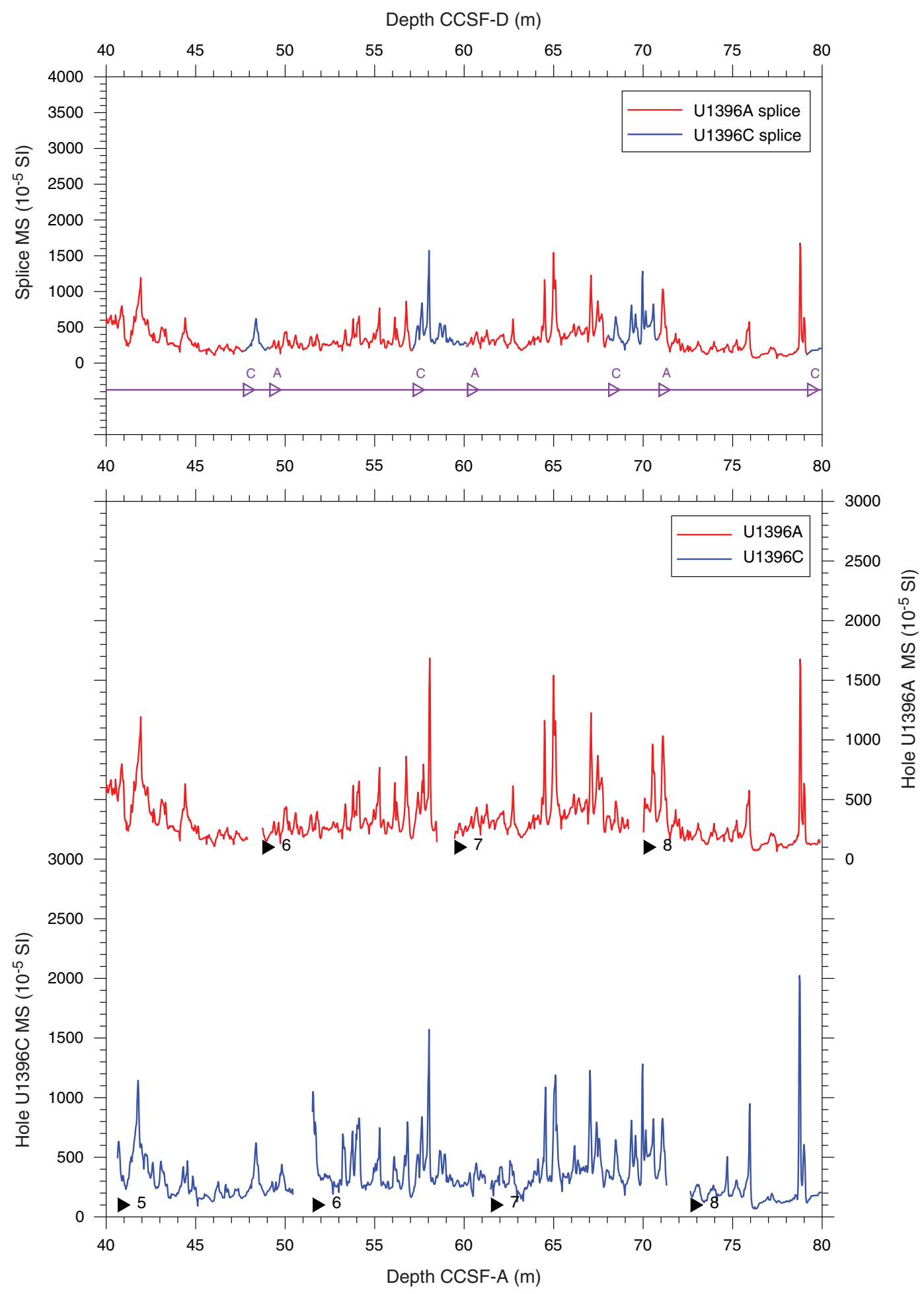
Figure F4 (continued). C. 80-120 m CCSF-A. (Continued on next page.)

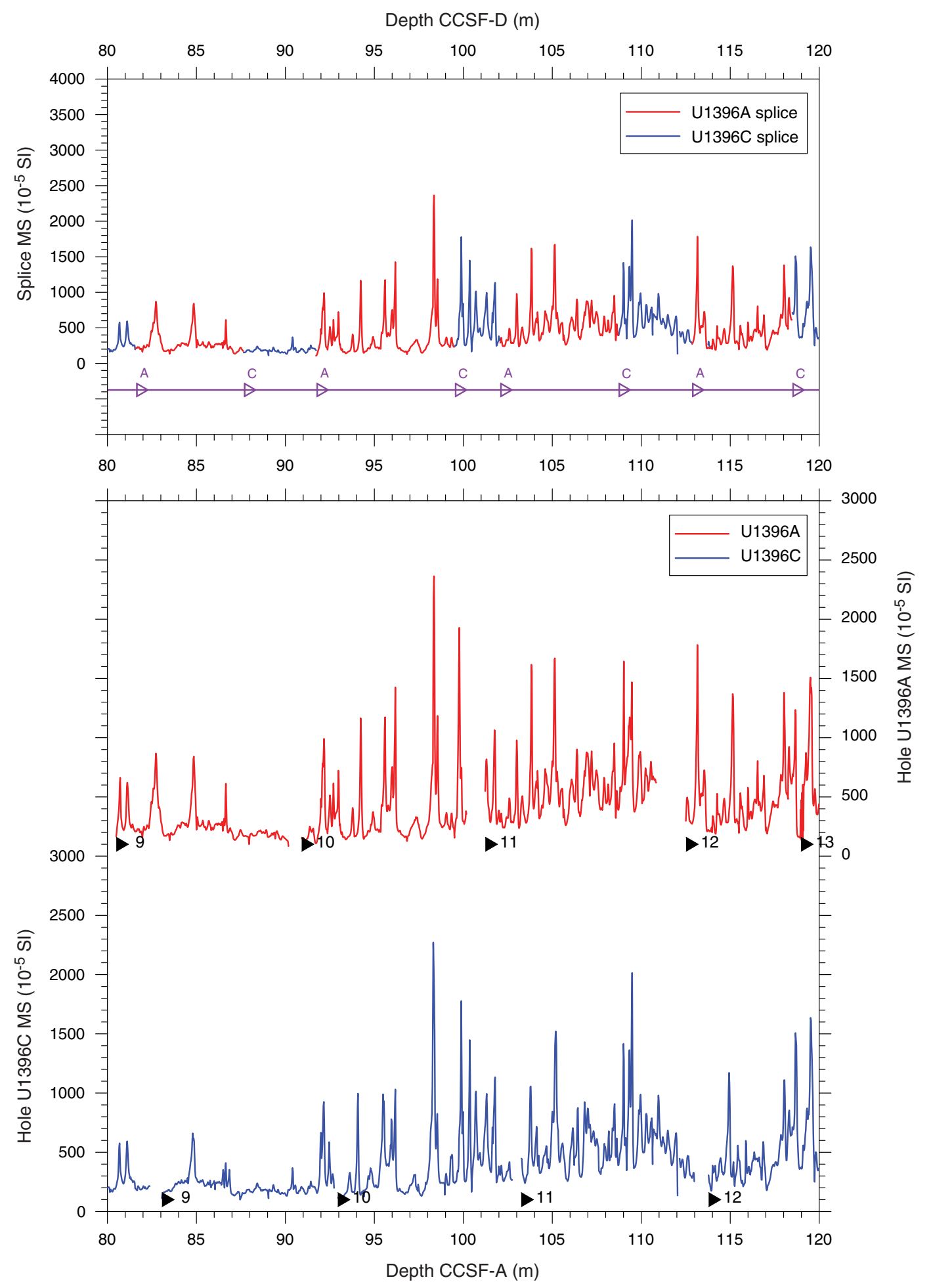


Figure F4 (continued). D. 120-160 m CCSF-A.
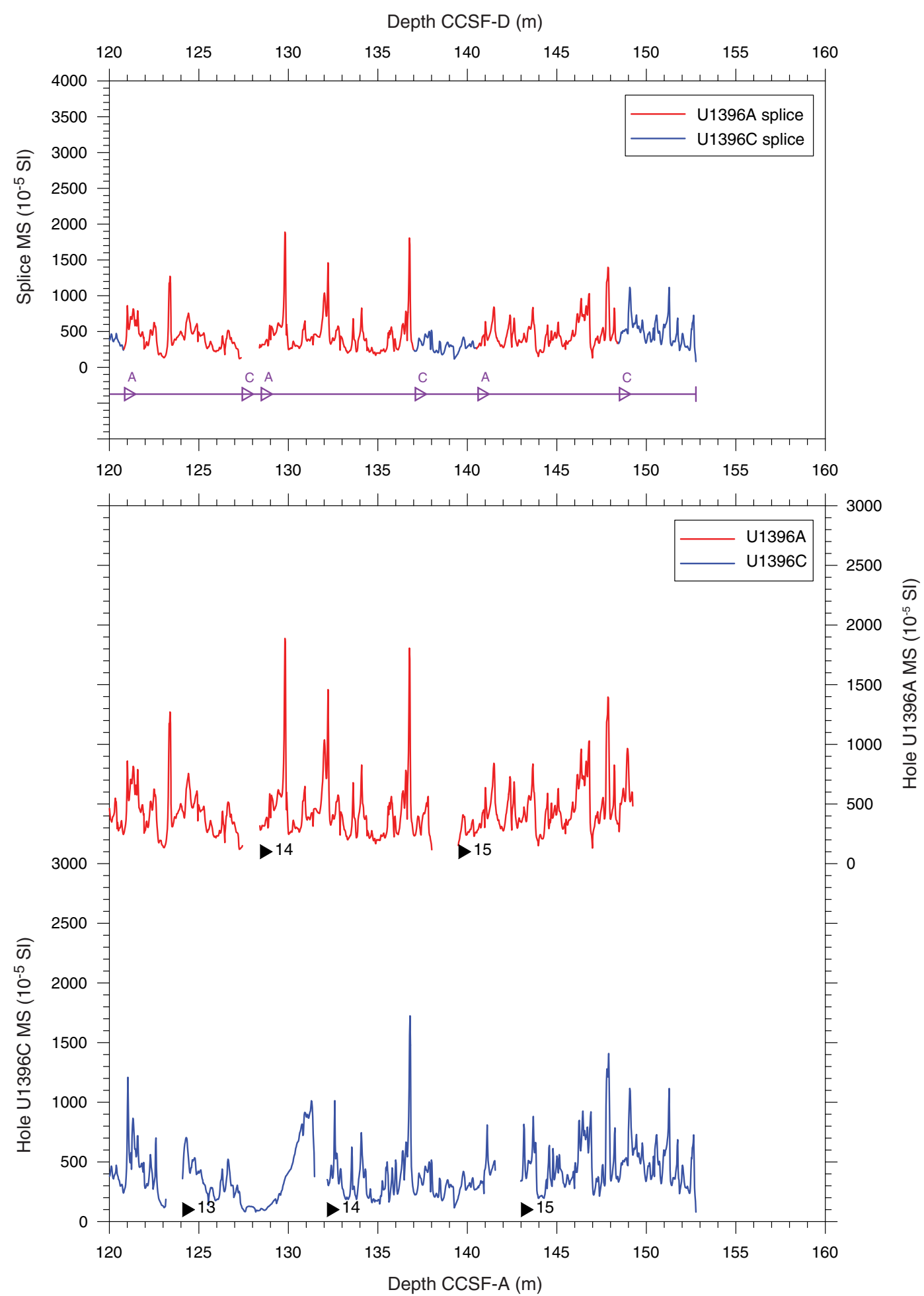
Figure F5. Core top depths for CCSF-A vs. CSF-A for Holes U1396A-U1396C. Lines fit through the core top depths of all holes gives an estimate of the amount the CCSF-A scale has to be compressed to derive the CCSFB scale. At Site U1396 this is estimated to be 0.9037 (90.37\%).

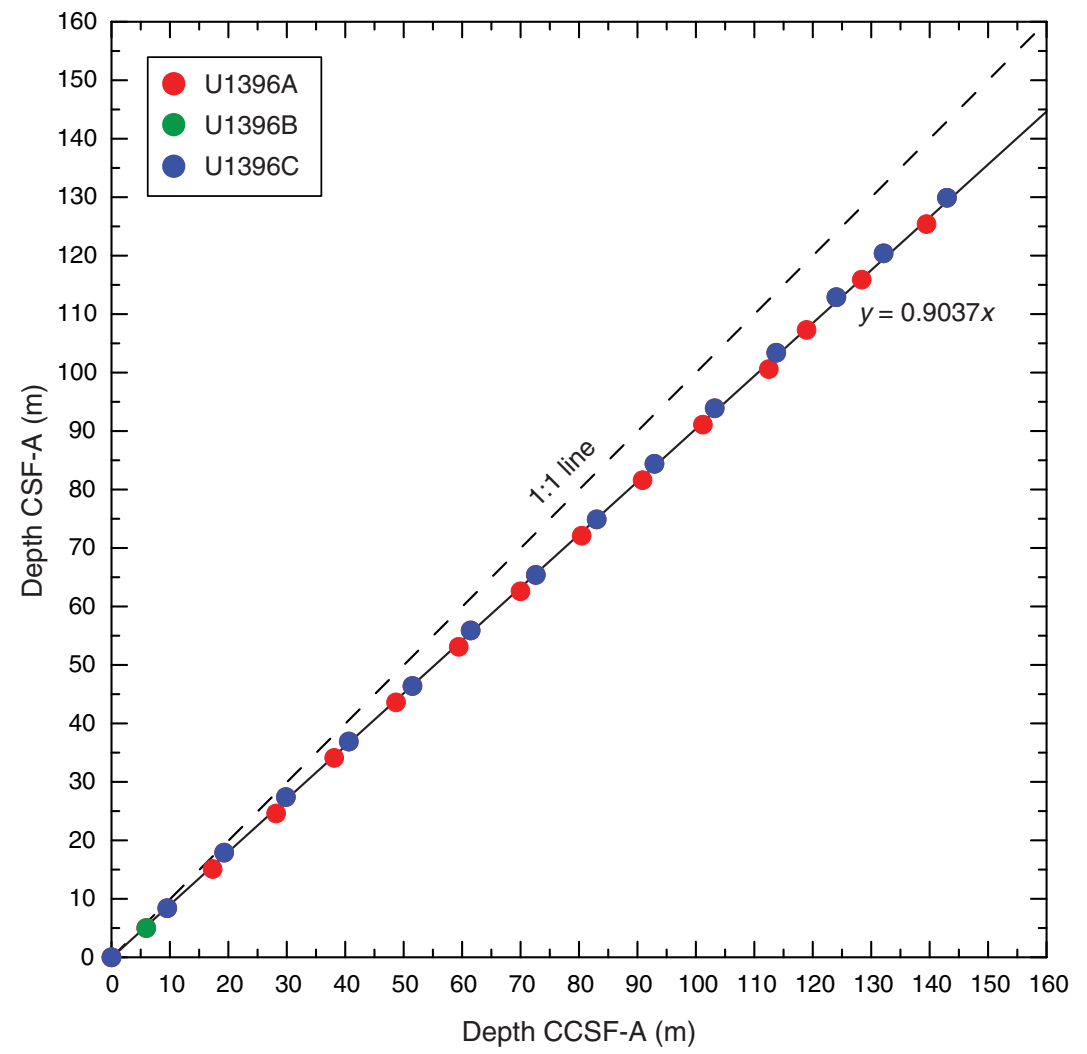


Figure F6. A. Depth vs. age model using the reversal midpoint depths from the shipboard paleomagnetic declination data and the magnetostratigraphic reversal record of Ogg (2012). B. Average sedimentation rate for the composite record (blue) plotted alongside the LR04 benthic $\delta^{18} \mathrm{O}$ stack (Lisiecki and Raymo, 2005; yellow) with a $100 \mathrm{ky}$ smoothed moving average (orange). Upper (red) and lower (green) sedimentation rate estimates were generated using the last and first points where the original and the new polarity are established and the slight difference in CCSF-A depth between cores. Average sedimentation rate: (i) 2.128-4.493 Ma (41.6 m/My), (ii) 04.493 Ma (30.9 m/My), and (iii) 0-2.128 Ma (19 m/My).
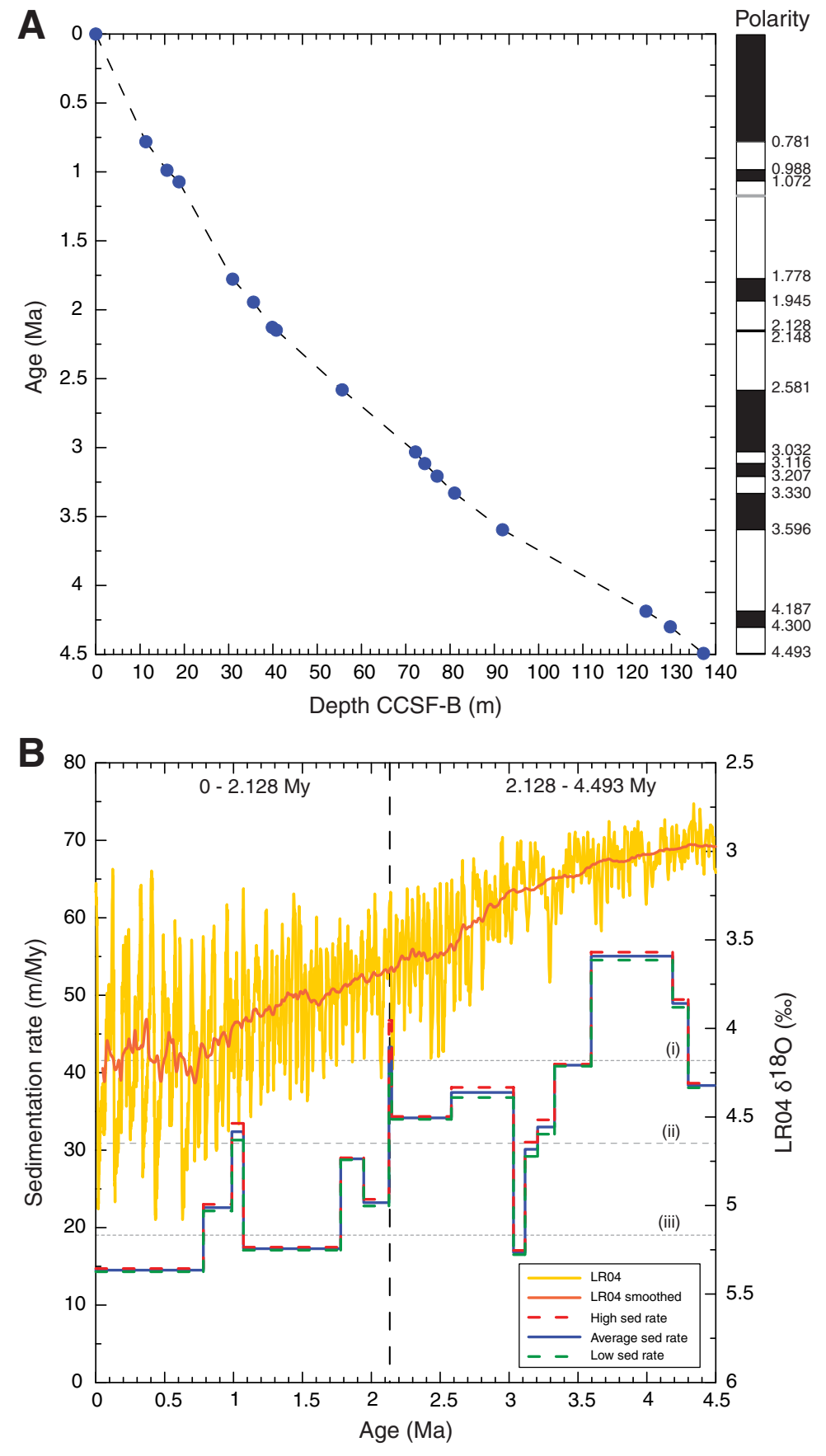
Table T1. Core length, CSF-A depth, CCSF-A depth, offset of the core relative to Core 340-U1396C-1H, and CCSF-B depth for each core retrieved from Site U1396.

\begin{tabular}{|c|c|c|c|c|c|}
\hline Core & $\begin{array}{l}\text { Length } \\
(\mathrm{m})\end{array}$ & $\begin{array}{l}\text { Top depth CSF-A } \\
(\mathrm{m})\end{array}$ & $\begin{array}{l}\text { Top depth CCSF-A } \\
(\mathrm{m})\end{array}$ & $\begin{array}{l}\text { CCSF-A offset relative } \\
\text { to top of Core } 1 \mathrm{H}(\mathrm{m})\end{array}$ & $\begin{array}{l}\text { Top depth CCSF-B } \\
(\mathrm{m})\end{array}$ \\
\hline \multicolumn{6}{|c|}{ 340-U1396A- } \\
\hline $1 \mathrm{H}$ & 5.63 & 0.00 & 0.00 & 0.00 & 0.00 \\
\hline $2 \mathrm{H}$ & 9.17 & 5.60 & & Too disturbed to correlate & \\
\hline $3 \mathrm{H}$ & 10.08 & 15.10 & 17.31 & 2.21 & 15.64 \\
\hline $4 \mathrm{H}$ & 10.23 & 24.60 & 28.17 & 3.57 & 25.46 \\
\hline $5 \mathrm{H}$ & 10.17 & 34.10 & 38.11 & 4.01 & 34.44 \\
\hline $6 \mathrm{H}$ & 10.17 & 43.60 & 48.69 & 5.09 & 44.00 \\
\hline $7 \mathrm{H}$ & 9.96 & 53.10 & 59.42 & 6.32 & 53.70 \\
\hline $8 \mathrm{H}$ & 10.14 & 62.60 & 69.99 & 7.39 & 63.25 \\
\hline $9 \mathrm{H}$ & 9.96 & 72.10 & 80.46 & 8.36 & 72.71 \\
\hline $10 \mathrm{H}$ & 9.58 & 81.60 & 90.88 & 9.28 & 82.13 \\
\hline $11 \mathrm{H}$ & 9.94 & 91.10 & 101.20 & 10.10 & 91.45 \\
\hline $12 \mathrm{H}$ & 6.78 & 100.60 & 112.48 & 11.88 & 101.65 \\
\hline $13 \mathrm{H}$ & 8.65 & 107.30 & 118.94 & 11.64 & 107.49 \\
\hline $14 \mathrm{H}^{*}$ & 9.98 & 115.90 & $128.38^{\dagger}$ & $12.48^{\dagger}$ & $116.02^{\dagger}$ \\
\hline $15 \mathrm{H}^{*}$ & 10.07 & 125.40 & $139.47^{\dagger}$ & $14.07^{\dagger}$ & $126.04^{\dagger}$ \\
\hline \multicolumn{6}{|c|}{ 340-U1396B- } \\
\hline $2 \mathrm{H}$ & 10.00 & 5.00 & 5.95 & 0.95 & 5.38 \\
\hline \multicolumn{6}{|c|}{ 340-U1396C- } \\
\hline $1 \mathrm{H}$ & 8.39 & 0.00 & 0.00 & 0.00 & 0.00 \\
\hline $2 \mathrm{H}$ & 10.07 & 8.40 & 9.54 & 1.14 & 8.62 \\
\hline $3 \mathrm{H}$ & 10.02 & 17.90 & 19.28 & 1.38 & 17.42 \\
\hline $4 \mathrm{H}$ & 9.95 & 27.40 & 29.84 & 2.44 & 26.97 \\
\hline $5 \mathrm{H}$ & 10.11 & 36.90 & 40.61 & 3.71 & 36.70 \\
\hline $6 \mathrm{H}$ & 10.03 & 46.40 & 51.50 & 5.10 & 46.54 \\
\hline $7 \mathrm{H}$ & 10.11 & 55.90 & 61.46 & 5.56 & 55.54 \\
\hline $8 \mathrm{H}$ & 10.07 & 65.40 & 72.61 & 7.21 & 65.62 \\
\hline $9 \mathrm{H}$ & 9.98 & 74.90 & 83.03 & 8.13 & 75.03 \\
\hline $10 \mathrm{H}$ & 10.09 & 84.40 & 92.91 & 8.51 & 83.96 \\
\hline $11 \mathrm{H}$ & 10.15 & 93.90 & 103.22 & 9.32 & 93.28 \\
\hline $12 \mathrm{H}$ & 9.57 & 103.40 & 113.75 & 10.35 & 102.80 \\
\hline $13 \mathrm{H}$ & 7.59 & 112.90 & 124.04 & 11.14 & 112.09 \\
\hline $14 \mathrm{H}^{*}$ & 9.68 & 120.40 & $132.12^{\dagger}$ & $11.72^{\dagger}$ & $119.40^{\dagger}$ \\
\hline $15 \mathrm{H}^{*}$ & 10.11 & 129.90 & $142.96^{\dagger}$ & $13.06^{\dagger}$ & $129.19^{\dagger}$ \\
\hline
\end{tabular}

${ }^{*}=$ cores in the floating CCSF-A scale. $\dagger=$ offset, CCSF-A, and CCSF-B depths derived through linear regression of Cores 340-U1396C-1H through $13 \mathrm{H}$. 
Table T2. Splice tie points, Site U1396.

\begin{tabular}{|c|c|c|c|c|c|c|c|c|}
\hline \multirow[b]{2}{*}{$\begin{array}{l}\text { Hole, core } \\
\text { section }\end{array}$} & \multirow[b]{2}{*}{$\begin{array}{l}\text { Tie point } \\
(\mathrm{cm})\end{array}$} & \multicolumn{2}{|c|}{ Depth } & & \multirow[b]{2}{*}{$\begin{array}{l}\text { Hole, core } \\
\text { section }\end{array}$} & \multirow[b]{2}{*}{$\begin{array}{l}\text { Tie point } \\
(\mathrm{cm})\end{array}$} & \multicolumn{2}{|c|}{ Depth } \\
\hline & & $\begin{array}{l}\text { CSF-A } \\
(\mathrm{m})\end{array}$ & $\begin{array}{c}\text { CCSF-A } \\
(\mathrm{m})\end{array}$ & & & & $\begin{array}{l}\text { CSF-A } \\
(\mathrm{m})\end{array}$ & $\begin{array}{c}\text { CCSF-A } \\
(\mathrm{m})\end{array}$ \\
\hline $340-$ & & & & & $340-$ & & & \\
\hline U1396C-1H-6 & 26 & 7.76 & 7.76 & Tie to & U1396B-2H-2 & 31 & 6.81 & 7.76 \\
\hline U1396B-2H-7 & 24 & 14.24 & 15.19 & Tie to & U1396C-2H-4 & 114 & 14.04 & 15.19 \\
\hline U1396C-2H-6 & 54 & 16.44 & 17.58 & Tie to & U1396A-3H-1 & 27 & 15.37 & 17.58 \\
\hline U1396A-3H-6 & 85 & 23.45 & 25.66 & Tie to & U1396C-3H-5 & 37 & 24.27 & 25.66 \\
\hline U1396C-3H-7 & 65 & 27.55 & 28.93 & Tie to & U1396A-4H-1 & 76 & 25.36 & 28.93 \\
\hline U1396A-4H-7 & 12 & 33.72 & 37.29 & Tie to & U1396C-4H-5 & 145 & 34.85 & 37.29 \\
\hline U1396C-4H-7 & 7 & 36.47 & 38.91 & Tie to & U1396A-5H-1 & 80 & 34.90 & 38.91 \\
\hline U1396A-5H-7 & 51 & 43.61 & 47.62 & Tie to & U1396C-5H-5 & 100 & 43.90 & 47.62 \\
\hline U1396C-5H-6 & 97 & 45.37 & 49.09 & Tie to & U1396A-6H-1 & 40 & 44.00 & 49.09 \\
\hline U1396A-6H-6 & 91 & 52.01 & 57.10 & Tie to & U1396C-6H-4 & 110 & 52.00 & 57.10 \\
\hline U1396C-6H-6 & 113 & 55.03 & 60.13 & Tie to & U1396A-7H-1 & 71 & 53.81 & 60.13 \\
\hline U1396A-7H-6 & 110 & 61.70 & 68.02 & Tie to & U1396C-7H-5 & 56 & 62.46 & 68.02 \\
\hline U1396C-7H-7 & 37 & 65.27 & 70.84 & Tie to & U1396A-8H-1 & 84 & 63.44 & 70.84 \\
\hline U1396A-8H-7 & 19 & 71.74 & 79.13 & Tie to & U1396C-8H-5 & 51 & 71.92 & 79.13 \\
\hline U1396C-8H-6 & 146 & 74.39 & 81.60 & Tie to & U1396A-9H-1 & 113 & 73.23 & 81.60 \\
\hline U1396A-9H-5 & 115 & 79.29 & 87.65 & Tie to & U1396C-9H-4 & 12 & 79.52 & 87.65 \\
\hline U1396C-9H-6 & 120 & 83.60 & 91.73 & Tie to & U1396A-10H-1 & 84 & 82.44 & 91.73 \\
\hline U1396A-10H-7 & 0 & 90.22 & 99.51 & Tie to & U1396C-10H-5 & 55 & 91.00 & 99.51 \\
\hline U1396C-10H-7 & 10 & 93.55 & 102.06 & Tie to & U1396A-11H-1 & 86 & 91.96 & 102.06 \\
\hline U1396A-11H-6 & 14 & 98.61 & 108.71 & Tie to & U1396C-11H-4 & 99 & 99.39 & 108.71 \\
\hline U1396C-11H-7 & 71 & 103.52 & 112.84 & Tie to & U1396A-12H-1 & 36 & 100.96 & 112.84 \\
\hline U1396A-12H-5 & 24 & 106.60 & 118.47 & Tie to & U1396C-12H-4 & 19 & 108.12 & 118.47 \\
\hline U1396C-12H-5 & 105 & 110.44 & 120.79 & Tie to & U1396A-13H-2 & 36 & 109.16 & 120.79 \\
\hline U1396A-13H-6 & 93 & 115.73 & 127.36 & Tie to & U1396C-13H-3 & 31 & 116.22 & 127.36 \\
\hline U1396C-13H-7 & 63 & 120.32 & 131.47 & Append to & U1396A-14H-1 & 0 & 115.90 & 128.43 \\
\hline U1396A-14H-6 & 110 & 124.51 & 137.04 & Tie to & U1396C-14H-4 & 52 & 125.28 & 137.04 \\
\hline U1396C-14H-6 & 104 & 128.78 & 140.54 & Tie to & U1396A-15H-1 & 103 & 126.43 & 140.54 \\
\hline U1396A-15H-6 & 141 & 134.33 & 148.44 & Tie to & U1396C-15H-4 & 91 & 135.34 & 148.44 \\
\hline
\end{tabular}


Table T3. Age of polarity transitions (Ogg, 2012); minimum, midpoint, and maximum CCSF-A depths of reversal boundaries in Holes U1396A-U1396C; and calculated sedimentation rate based on the midpoint depth using the CCSF-B depth scale.

\begin{tabular}{|c|c|c|c|c|c|}
\hline Polarity zone & $\begin{array}{c}\text { Age } \\
\text { Ogg (2012) } \\
(\mathrm{Ma})\end{array}$ & $\begin{array}{l}\text { Top depth } \\
\text { CCSF-A (m) }\end{array}$ & $\begin{array}{l}\text { Midpoint depth } \\
\text { CCSF-A }(\mathrm{m})\end{array}$ & $\begin{array}{l}\text { Bottom depth } \\
\text { CCSF-A }(m)\end{array}$ & $\begin{array}{c}\text { CCSF-B } \\
\text { Sed. rate } \\
\text { (midpoint) } \\
\text { (m/My) }\end{array}$ \\
\hline \multicolumn{6}{|l|}{ 340-U1396A- } \\
\hline C1n (B) Brunhes/Matuyama & 0.781 & $12.35^{\star}$ & $12.51^{*}$ & $12.67^{*}$ & 14.49 \\
\hline C1r.1n (T) Jaramillo & 0.988 & 17.79 & 17.88 & 17.97 & 23.33 \\
\hline C1r.1n (B) Jaramillo & 1.072 & 20.80 & 20.94 & 21.08 & 32.92 \\
\hline C2n (T) Olduvai & 1.778 & 34.30 & 34.35 & 34.40 & 17.17 \\
\hline C2n (B) Olduvai & 1.945 & 39.36 & 39.56 & 39.76 & 28.19 \\
\hline$C 2 r .1 n(T)$ Reunion & 2.128 & 43.97 & 44.10 & 44.23 & 22.42 \\
\hline C2r.1n (B) Reunion & 2.148 & 45.16 & 45.21 & 45.26 & 50.16 \\
\hline C2r.2r (B) Gauss/Matuyama & 2.581 & 61.44 & 61.58 & 61.72 & 34.17 \\
\hline C2An.1r (T) Keana & 3.032 & 80.61 & 80.67 & 80.73 & 38.25 \\
\hline C2An.1r (B) Keana & 3.116 & 82.14 & 82.23 & 82.32 & 16.78 \\
\hline C2An.2r (T) Mammoth & 3.207 & 85.32 & 85.38 & 85.44 & 31.28 \\
\hline C2An.2r (B) Mammoth & 3.330 & 89.64 & 89.70 & 89.76 & 31.74 \\
\hline C2An.3n (B) Gilbert/Gauss & 3.596 & 101.62 & 101.67 & 101.72 & 40.67 \\
\hline C3n.1n (T) Cochiti & 4.187 & 137.29 & 137.67 & 138.05 & 55.05 \\
\hline C3n.1n (B) Cochiti & 4.300 & 143.57 & 143.61 & 143.65 & 47.50 \\
\hline \multicolumn{6}{|l|}{ 340-U1396C- } \\
\hline C1n (B) Brunhes/Matuyama & 0.781 & 12.67 & 12.69 & 12.72 & 14.68 \\
\hline C1r.1n (T) Jaramillo & 0.988 & 17.74 & 17.79 & 17.84 & 22.27 \\
\hline C1r.1n (B) Jaramillo & 1.072 & 20.65 & 20.80 & 20.95 & 32.38 \\
\hline C2n (T) Olduvai & 1.778 & 34.00 & 34.30 & 34.60 & 17.28 \\
\hline C2n (B) Olduvai & 1.945 & 39.31 & 39.40 & 39.49 & 27.60 \\
\hline$C 2 r .1 n(T)$ Reunion & 2.128 & 44.10 & 44.19 & 44.28 & 23.65 \\
\hline C2r.1n (B) Reunion & 2.148 & 44.99 & 45.11 & 45.24 & 41.57 \\
\hline C2r.2r (B) Gauss/Matuyama & 2.581 & 61.48 & 61.59 & 61.70 & 34.39 \\
\hline C2An.1r (T) Keana & 3.032 & 79.84 & 79.89 & 79.94 & 36.67 \\
\hline C2An.1r (B) Keana & 3.116 & 82.24 & 82.25 & 82.26 & 25.39 \\
\hline C2An.2r (T) Mammoth & 3.207 & 85.18 & 85.29 & 85.40 & 30.19 \\
\hline C2An.2r (B) Mammoth & 3.330 & 89.54 & 89.78 & 90.02 & 32.99 \\
\hline C2An.3n (B) Gilbert/Gauss & 3.596 & 101.57 & 101.84 & 102.12 & 40.97 \\
\hline C3n.1n (T) Cochiti & 4.187 & 137.43 & 137.55 & 137.68 & 54.60 \\
\hline C3n.1n (B) Cochiti & 4.300 & 143.48 & 143.67 & 143.86 & 48.94 \\
\hline C3n.2n (T) Nunivak & 4.493 & 151.61 & 151.86 & 152.11 & 38.35 \\
\hline
\end{tabular}

* = depths reported from Hole U1396B not Hole U1396A. Maximum depth = last point that stable polarity was defined before entering a transitional stage, minimum depths $=$ first stable polarity after the magnetic reversal, midpoint $=$ average of the two. $B=b a s e$ of transition, $T=$ top of transition. The CCSF-B depths of these horizons can be calculated using the regression in Figure F5. 